\title{
The Case for International Antitrust
}

\author{
By \\ Andrew Guzman*
}

We already live in a world of international competition policy. Although no international institution or agreement governs the subject, firms doing business internationally face a de facto regime generated by the overlap of domestic regimes. The question, then, is not whether there should be an international competition policy, but rather whether the existing system is better than what might otherwise exist. Examination of how globalization and trade interact with domestic competition policies and how they influence the incentives of domestic policymakers suggests there is significant value in increased cooperation among states. Furthermore, this cooperation must extend beyond the current set of information-sharing agreements and bilateral negotiations to include substantive antitrust issues.

I.

The CASe for CoOperation

\section{A. The Costs of Noncooperation}

The regulation of international activity by national regulators generates costs and benefits that are not fully internalized by domestic decision makers. This failure to take all effects into account is inevitable in a world with neither a single governmental body charged with establishing objectives and policies nor a forum in which domestic authorities can negotiate effectively over their domestic policies and the international implications thereof. Among the costs generated by the current noncooperative system are the effects of multiple regulators reviewing a single transaction (including redundant filing and reporting obligations), the risk of biased prosecutions based on the nationalities of the parties, and the impact of international activity on the substantive rules chosen by states.

\section{Transaction Costs}

The most obvious problem is the duplication of costs. Firms must satisfy regulatory agencies in many countries, meaning they must hire legal representation in each state and meet the reporting and disclosure requirements of each jurisdiction. At a minimum, this generates duplicative costs and wastes time. It

* Professor of Law, University of California, Berkeley (Boalt Hall). This Article appears in substantially similar form in Competition LAws in CONFLICT: ANTTTRUST JuRISDiction IN THE Global Economy (Michael S. Greve \& Richard A. Epstein eds., 2004), published by AEI Press. 
may also impose conflicting requirements on firms. Additional costs are borne by the regulatory agencies that must review a firm's documents. Because each country's regulators act independently, each country must review and evaluate the firm's filing de novo, generating redundancy and waste in the review process.

\section{Bias}

When transactions cross borders, regulatory authorities review the activities of both foreign and domestic firms. Agencies will be tempted to be lenient toward locals and tough on foreigners in this review process, even if no such double standard is called for in the relevant legislation. Furthermore, even if the process is unbiased, foreign firms subject to review-as well as their governments-may believe that an unfavorable ruling represents an attempt to penalize foreign firms. This perception is itself costly because it may chill firm behavior or generate hostility among states.

Ample evidence suggests that states are, indeed, biased in their application of competition policy. Export cartel exemptions are the most obvious example. ${ }^{1}$ Perhaps less obvious are the industry exemptions that American law provides to several privileged industries, including international aviation, international energy, international ocean shipping, and international communications. To the extent local firms benefit from these exemptions, they enjoy an advantage over their foreign rivals. Although it is more difficult to demonstrate bias at the administrative level than at the statutory level, favoritism toward locals is likely in the selection of cases to pursue. One would expect more aggressive prosecution of foreign firms than domestic firms, either because the regulators themselves view local firms more favorably or because political leaders bring pressure to bear on regulators and encourage them to pursue foreign firms rather than national champions.

The increased transaction costs of noncooperation and the impact of bias are familiar in the international antitrust literature, so this article does not dis-

1. American antitrust laws have long provided an explicit exception for export cartels. The Webb-Pomerene Act, 15 U.S.C. $\$ \S 61-66$ (2000), adopted in 1918, creates an exemption from the Sherman Act and from Section 7 of the Clayton Act for export associations formed for the sole purpose of engaging in export trade and actually engaged solely in such export trade. Export associations must register with the FTC. $\$ 65$. The Act does not protect activity that has an anticompetitive effect within the United States, and there are other restrictions on its applicability. See A. Paul Victor, Export Cartels: An Idea Whose Time Has Passed, 60 ANTrTRust L.J. 571,572 (1991). By the early 1980s, the Webb-Pomerene Act was, for various reasons, not being used by exporters and was, in that sense, no longer effective. See id. at 573-74. Congress responded by enacting the Export Trading Company Act of 1982, 15 U.S.C. $\S \S 4001-16$ (2000), and the Foreign Trade Antitrust Improvements Act, 15 U.S.C. § 6a (2000). The Export Trading Act allows a firm to apply for and receive a Certificate of Review from the Secretary of Commerce by demonstrating that its activities will not have harmful effects on the United States. See 15 U.S.C. \& 4013. The certificate does not grant complete immunity to the firm, but it does provide immunity from treble damages and criminal liability. It also establishes a presumption of legality for any activity that is covered by the certificate. \$ 4016(b)(3). The Foreign Trade Act offers a more direct exemption for export activity. It exempts from Sherman Act prosecution activity that does not have a "direct, substantial, and reasonably foreseeable" effect on American commerce. 15 U.S.C. \& 6a(1) (2000). Other countries have similar exemptions. 
cuss them further. It focuses instead on the question of how and why international trade distorts substantive antitrust policies and makes sound policymaking virtually impossible without cooperation. The analysis that follows requires only the modest assumption that each state pursues its own interests without regard for the interests of other states. If this is so, international trade will distort decisions on antitrust relative to the regime each state would choose if it were a closed economy. These systematic and predictable deviations represent attempts to externalize the costs and internalize the benefits of the exercise of market power across borders. The analysis holds for any reasonable assumption about government behavior, whether based on public choice assumptions or the alternative hypothesis that governments seek to maximize the well-being of citizens. $^{2}$ To keep the presentation simple, I assume that states do not consider foreign costs and benefits at all, but even this assumption of complete disregard for foreigners could be relaxed. The only absolutely necessary assumption is that local interests are favored over foreign interests.

\section{B. International Trade and Domestic Policy}

To see how international trade can distort policy decisions in antitrust, suppose that a country exports virtually all of its production in imperfectly competitive industries. ${ }^{3}$ (Only imperfectly competitive industries are of concern here because firms in competitive industries are not problematic from an antitrust perspective.) When domestic firms engage in activities that might be considered anticompetitive, the great majority of the harm is felt by foreigners, whereas the benefits are felt by local firms. Policymakers, looking only to local costs and benefits, will take into account all of the resulting benefits enjoyed by firms, but will consider only that fraction of the harm that is felt by local consumers. A government designing an antitrust policy in this context would, therefore, favor the interests of producers over those of consumers. Note that this effect operates in addition to any preference for one group or the other generated by domestic political concerns. One way to think about this is to imagine that the policymaker adjusts the payoffs to local consumers and producers to reflect the relative weights or priorities that he or she assigns to each. In contrast to local interests, foreign interests are not considered at all-they receive a weight of zero. Thus, trade causes the country to favor producers over consumers more than would be the case in the absence of international trade.

To illustrate, imagine that a state favors firm interests over consumer interests. If the country is a closed economy, it will adopt policies that favor firms but, in evaluating policy options, will give consumer interests at least some

2. For example, if government officials behave as public choice models predict--pursuing campaign contributions, political support, and a good public image-the discussion that follows applies as long as it is primarily domestic interests that influence the goals of those officials. In other words, as long as domestic contributors dominate campaign contributions, important political supporters are locals, and the public image that matters is domestic, the discussion that follows is consistent with public choice assumptions.

3. See Andrew T. Guzman, Is International Antitrust Possible?, 73 N.Y.U. L. REv. 1501 (1998), for a more detailed discussion of the impact of trade on competition policies. 
weight. Now consider a country that has the same political economy but that exports most of the production of its imperfectly competitive industries. Because the political economy favors firms, the interests of domestic producers are still weighted more heavily than those of domestic consumers. In addition to this effect, the impact of the antitrust regime on consumers is underestimated because foreign consumers receive zero weight in the government's calculus. This generates policies that are still more favorable to firms, at the expense of consumers, than was the case in the absence of trade.

Several strategies are available to governments that wish to favor firms over consumers. The easiest of these, the already-discussed export cartel exemption, is a relatively crude instrument because it applies only if all of a firm's production is exported. A more nuanced strategy is to change the state's substantive laws. This benefits all firms, including those that sell some of their goods domestically. Returning to the example of a country that exports most but not all of its production in imperfectly competitive industries, the government could react to the pattern of trade by weakening its competition laws. This strategy opens the door to more anticompetitive activity by local firms than would be the case in the absence of trade, yet it retains some limits on conduct to protect local consumers.

Imports generate an analogous distortion. If a country is able to regulate extraterritorially, it has an incentive to tighten its policy (relative to what a closed economy would do) in response to the importation of goods in imperfectly competitive markets. In the case of imports, the full amount of harm suffered by local residents is included in the policy calculus, whereas only the benefits to local firms are considered. As with exports, this generates a predictable distortion regardless of how policymakers weigh the interests of firms and consumers.

The combination of trade and consumption patterns in imperfectly competitive markets suggests how a rational state's competition policy will differ from a closed-economy baseline. Assume that there are two kinds of goods: those that trade in competitive markets and those that trade in imperfectly competitive markets. Firms whose goods trade in competitive markets have no market power and therefore cannot engage in conduct that raises competition policy concerns. Firms whose goods trade in imperfectly competitive markets, however, enjoy market power, and states attempt to regulate these firms through the use of antitrust laws. For simplicity it is assumed that if a country's firms are responsible for $\mathrm{x}$ percent of global production of imperfectly competitive goods, those same firms enjoy $x$ percent of the monopoly rents generated by the sale of those goods. ${ }^{4}$ The government of that country, then, will take into account $x$ percent of the producer surplus generated by a change in its policies. Thus, for example, a country's relaxation of its competition policies might lead to an increase in producer surplus. But the government ignores the portion of that sur-

4. This assumption could be relaxed without changing the analysis, but at a cost of considerably more complexity. 
plus that falls outside the country. If the same country's consumers account for y percent of global consumption of goods sold in imperfectly competitive markers, then the government will take into account y percent of the global effect of its policies on consumers.

The net effect of trade, then, depends on the ratio of a country's global share of production to its global share of consumption of imperfectly competitive goods. Notice that a closed economy would be one in which these are equal $(x=100=y)$. If a country is a net exporter (meaning that its share of global production exceeds its share of consumption, $x>y$ ), the country will take into account a larger portion of its policy's impact on producers than on consumers. Relative to what it would do if it were a closed economy, the country will favor the interests of producers, yielding a more permissive competition policy regime. If a country is a net importer of these goods $(x<y)$, the opposite is truethe preferred policy is stricter than would be the case in a closed economy. International activity, then, causes a state's domestic antitrust laws to deviate in systematic and predictable ways from what that state would choose if it were a closed economy. These deviations represent attempts to externalize the costs and internalize the benefits of the exercise of market power across borders.

\section{Choice of Law}

In part because of the divergent interests just discussed, the current level of cooperation in international competition policy is quite modest. This lack of cooperation, however, has generated an "accidental" competition policy regime created by the interaction of national regimes and their choice-of-law rules. Because of these rules, a single activity may be overregulated or underregulated, depending on how it intersects with jurisdictional policies. Independent from, and in addition to, the distorting effects of international trade, the choice-of-law rules chosen by domestic systems interact to create a complex regulatory system that affects international activity but that is not controlled by any single authority.

\section{Overregulation}

The activities of firms doing business in the United States, the European Union (EU), and other states that apply their laws extraterritorially are often within the jurisdiction of two or more domestic regimes. The net effect is a more restrictive and burdensome set of substantive rules than exists under the legal regime of any single state. Consider a proposed merger of two or more large firms doing business in both the United States and the EU and subject to merger review in both jurisdictions: those firms face more regulation than they would under either of the domestic regimes. First, even if the substantive criteria for review were identical in the United States and Europe, the proposed merger could go forward only if both regulatory authorities permitted it. This duplicative review would not matter if regulatory review were a precise science, but of course it is not. Any review by regulators is affected by the idiosyncratic views of the individual reviewers, the culture of the reviewing agency, the politi- 
cal climate in the country, and other factors. Requiring the approval of two independent regulatory bodies, therefore, increases the likelihood that an activity will be deemed a violation and increases the regulatory burden.

Second, firms doing business in states that apply their laws extraterritorially face a heightened burden because the substantive provisions of those laws are not identical across jurisdictions. Where legal rules vary across jurisdictions and all such rules must be followed, the relevant international legal regime consists of a medley of the strictest elements of each national regime. Suppose, for example, the activities of a firm are subject to the competition laws of Countries A and B. Assume that Country A has, relative to Country B, a restrictive policy with respect to horizontal restraints of trade and a permissive policy with respect to vertical restraints. For its own reasons, Country A believes this combination represents the optimal competition policy. Country B, however, believes that its regime, which is relatively permissive with respect to horizontal restraints but restrictive with respect to vertical restraints, is optimal. Firms subject to the jurisdiction of both states face a de facto regime that includes the strict horizontal restraint regulations of Country $\mathrm{A}$ and the strict vertical restraint regulations of Country B. This is a stricter policy than either Country A or Country B believes should exist.

In short, firms doing business in both the United States and the EU face an international competition policy regime that is more burdensome than the regime of either the EU or United States and very likely more restrictive than what either jurisdiction would choose if it were a closed economy. The only way to prevent such overregulation is to end the extraterritorial assertion of jurisdiction-which would impose its own costs, as discussed below-or enter into some form of cooperative policymaking.

\section{Underregulation}

Although some jurisdictions, including the United States, apply their laws extraterritorially, many countries (including most developing states) either do not have effective competition laws or do not apply their competition laws to conduct beyond their borders. ${ }^{5}$ Business activity that takes place within these states also faces an accidental international competition policy, but its contours are more complex than is the case for businesses operating in the United States and the EU.

Consider, first, the impact of international trade on the domestic competition policy of a country that does not apply its laws extraterritorially. With respect to imported goods, the country is unable to prevent anticompetitive ac-

5. A country might choose to limit the jurisdiction of its laws to territorial conduct, or it may simply lack the ability as a practical matter to apply its laws abroad. Historically, every nation limited its laws to conduct within its territory. See, e.g., Am. Banana Co. v. United Fruit Co., 213 U.S. 347 (1909). Even as extraterritoriality has become accepted, states have retained limits on the reach of their laws. In the United States, for example, the reach of the securities laws is limited by a variety of rules. Many developing countries have little choice but to opt for a territorial jurisdiction because they lack both the capacity and the political power to enforce their laws more broadly. 
tivity by the foreign producers of those goods. Recognizing this, when policymakers shape the state's substantive competition policy, they only consider the impact of the law on domestic production. Put another way, because the domestic law cannot affect the behavior of foreign firms, the optimal policy for the state is the same as it would be if there were no imports. As long as domestic firms sell at least some of their products abroad, then, the state has an incentive to adopt competition laws that are more permissive than would be the case in a closed economy. (If local producers in imperfectly competitive markets only sell domestically, the local competition policy will be the same as it would be in a closed economy.) This is so because a tightening of the antitrust laws affects both producers and consumers. More restrictive laws hurt producers, while more competitive pricing benefits consumers. ${ }^{6}$ Policymakers will tighten the laws until the marginal benefit to consumers equals the marginal cost to producers. $^{7}$ In a closed economy, all gains enjoyed by consumers are taken into account because all consumers are local. In a trading economy, however, this is not so. At least some consumers are located abroad, and the policymaker ignores all benefits conferred on these consumers by domestic laws. Because some of the benefits of tougher laws are ignored, the optimal policy for the state is less restrictive in the presence of trade.

One of the predictions of this analysis is that small, open economieswhose firms export a high percentage of their goods and whose consumers import a high percentage of their consumption-will have weak or nonexistent antitrust laws. This prediction is consistent with the empirical observation that small states rarely have significant antitrust laws. It is also consistent with the experience of the EU. When competition policy was made at the national level, the EU's competition policies were relatively permissive. When policy moved to the regional level (and as extraterritoriality came to be the practice), the EU adopted a much stricter antitrust regime. ${ }^{8}$

If no states applied their laws extraterritorially, the above analysis would lead to the conclusion that substantive competition laws are systematically more lenient than would be the case if all costs and benefits were taken into account. In fact, however, the conduct of these states that apply their laws extraterritorially affects the legal regime facing many firms, including some that do business in states that do not apply their laws to foreign conduct.

Because the United States and the EU apply their laws to foreign conduct that has a local effect, firms active in those markets are at least potentially sub-

6. Consumers need not always benefit from stricter antitrust laws, of course. In particular, they can be harmed if the tougher laws prevent firms from achieving efficiency gains. Even in that event, however, domestic policies will be weaker for a trading country without extraterritoriality than for a closed economy.

7. To account for the realities of the political economy, it may be more accurate to say that policymakers will tighten the laws until the net marginal gain to those policymakers is zero. As long as the policymakers' gains from tougher laws stem from the benefits to consumers and the costs stem from the burden on producers, the analysis presented above applies. That policymakers may weigh producer interests more heavily than consumer interests (or vice versa) does not affect the results.

8. See Guzman, supra note 3 , at $1537-38$. 
ject to the laws of both jurisdictions. This overlap is relevant to all states, including those that do not apply their laws extraterritorially, because the EU and the U.S. regimes affect the global operations of producers. Imagine, for example, that two or more producers of passenger aircraft wish to merge. If they do so, they will enjoy greater market power, earn more profits for the newly merged firm, and increase the price of aircraft. A state that does not apply its laws extraterritorially can only reach the proposed merger if one of the firms happens to be located within its borders, and even then it can-at most-prevent its local firm from participating. The same proposed merger, however, will trigger jurisdiction in both the EU and the United States and can be blocked by either of those states. If the merger is blocked, this affects all states, including those that do not apply their laws extraterritorially. Economic activity within these states, then, is influenced by the competition policies of foreign states. This can yield benefits for a state that does not apply its laws extraterritorially, because it is able to free ride on the regulatory supervision of those countries that do apply their laws in this way.

A strategy of free riding is especially effective in the presence of an open trading regime because a firm can retain local market power only if it also has global market power. A firm that operates monopolistically locally but not internationally will earn excess profits from its local operations, attract competitors from abroad, and see its market power erode. If, however, a firm has market power internationally, it is likely to sell its products into the United States, the EU, or both.

Although free riding can operate as a substitute for domestic competition policy, it falls short of a satisfactory legal regime for states that do not apply their laws extraterritorially. In addition to the distortions already discussed, there are at least two further reasons why free riding is likely to yield suboptimal policy. First, if the impact of a particular activity is small in developed states but large in developing states, neither the EU nor the United States may bother to pursue a case. There is no reason to think that the costs and benefits of an activity are the same in all countries, especially when comparing developing countries to developed ones. As a result, a decision on whether to bring a case in the United States or the EU may be quite different from what is in the interests of a developing country. ${ }^{9}$ Similarly, there are at least some goods that are sold only regionally (for example, regional periodicals) and that will not trigger jurisdiction in the United States or the EU.

Second, even when goods trade globally, the existence of a strong and effective competition policy in the United States and the EU, complete with extraterritorial application, may not prevent firms from engaging in anticompetitive conduct in other countries. Consider how a profit-maximizing firm with market power and global sales will react if it faces effective competition laws in some but not all of the states in which it does business. In states with an effective

9. In the market for pharmaceuticals designed to treat tropical diseases, for example, firms with market power may act in a way that would violate the substantive laws of the United States and the EU without attracting the attention of regulators in either jurisdiction. 
policy, the firm would restrain its anticompetitive activities so as to remain within the law. But the firm need not sell at the same price everywhere. As long as arbitrage between markets is costly, the firm can charge higher prices in markets without effective competition laws or without laws that apply extraterritorially. Although the United States and the EU have jurisdiction over the firm, they have no reason to pursue a case if the firm's conduct in the United States and the EU mimics that of a firm in a competitive industry. Countries whose laws cannot reach the firm, then, may not be able to free ride on the competition laws of the EU and the United States. The empirical evidence suggests exactly this sort of market segmentation and price discrimination has taken place. ${ }^{10}$

Overall, the de facto competition policy regime that exists in countries that do not apply their laws extraterritorially is almost certainly a mix of overregulation in some markets (where EU and U.S. laws apply) and underregulation in other markets (where those laws do not apply or are not effective). Cooperation has the potential to reduce the level of regulation in the former markets and increase it in the latter.

\section{The Promise of Cooperation}

If we assume that governments pursue some measure of national welfare, government decisions in a closed economy represent optimal decisions in the sense that they take into account all relevant costs and benefits. Deviations from this closed economy policy represent attempts by states to externalize cost while internalizing benefits. The resulting policies are, by assumption, domestically optimal but are suboptimal from a global perspective because some costs and benefits are ignored. If we instead assume a public choice model of government, the analysis is more complex. Under this model, trade causes policies to move away from the closed economy policy, which may represent a move toward or away from the optimal policy, depending on the way in which public choice issues affect decision making.

To isolate the impact of trade on policy, assume for the moment that there is an international consensus on the objectives of antitrust policy and the appropriate way to achieve those objectives. Even under these assumptions, noncooperative states will not all adopt the same policies: Net importers will adopt relatively strict antitrust laws (assuming they can apply their laws extraterritorially), and net exporters will adopt relatively permissive laws. Nevertheless, because states have a shared view of the optimal antitrust law for a closed economy, they will be able, absent transaction costs, to reach an agreement that

10. See, e.g., Margaret Levenstein \& Valerie Suslow, World Bank, Private International Cartels and Their Effect on Developing Countries, (Background Paper for the World Development Report, 2001), available at http://www-unix.oit.umass.edu/ maggie//WDR2001.pdf; John M. Connor, Global Price Fixing: Our Customers Are the Enemy (2001); Lawrence J. White, Lysine and Price Fixing: How Long? How Severe?, 18 Rev. Indus. Org. 23 (2001); Julian L. Clarke \& Simon J. Evenett, AEI-Brookings Joint Ctr. for Regulatory Studies, The De-

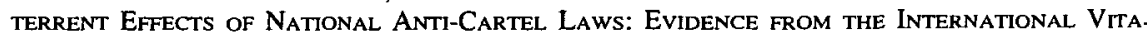
MINS CARTEL, (Working Paper 02-13, Dec. 2002), available at http://www.aei.brookings.org/admin/ authorpdfs/page.php?id=218. 
implements that policy on a global scale. That is, states will agree on the most efficient global antitrust regime. This result is an application of basic theories of federalism, which suggest that decision-making responsibility should be assigned to the lowest level of government that is capable of internalizing economic externalities. ${ }^{11}$ In the case of antitrust policy, the externalities provide a strong argument for international regulation or cooperation.

Assuming a consensus of opinion and zero transaction costs is, of course, wholly unrealistic. The proper role of competition policy is a subject of considerable disagreement, and international negotiations are plagued by transaction costs. In recognition of these realities, we now relax these assumptions.

For the moment, continue to assume that transaction costs are zero, but allow that the objectives of competition policy differ from state to state. There are any number of reasons why states might have divergent goals. For example, some countries may understand what competition policy can and cannot do, and others may simply be mistaken. In this situation, agreement may be possible through dialogue and debate. Over time, one view may come to be accepted while the other is discredited, and international agreement on a common policy will be possible.

Another possibility is that disagreements are not the result of differences in information but, rather, differences in preferences. Diversity of preferences may exist for many reasons, ranging from differing priorities to differing conditions in domestic markets to different interest group constellations. If the preferences differ, the sharing of information cannot by itself generate consensus. This will not preclude an optimal agreement, however, so long as states can compensate one another for accepting a policy that differs from their preferred policy. Just as parties to a contract will bargain to maximize the joint value of the agreement, states will bargain to maximize the joint value of competition policy. Imagine, for example, that one state prefers a relatively restrictive policy toward mergers-perhaps because it values the existence of small and medium-sized businesses-while another prefers a more permissive merger policy based solely on efficiency grounds. This difference in preferences can be overcome through the use of transfer payments. An agreement will be struck in which the party with the stronger preferences gets its preferred policy and in exchange makes a compensatory payment to the other state.

The same result holds if the divergent preferences stem from the tradeinduced distortions discussed earlier. Specifically, the parties would enter into an agreement that puts in place the globally optimal competition policy and provides for a transfer from states that benefit from this policy to states that suffer losses relative to their noncooperative payoffs. Because cooperative policy is globally optimal, it must be the case that there are sufficient gains for a Pareto improving agreement to be reached.

11. See, e.g., Robert P. Inman \& Daniel L. Rubinfeld, Rethinking Federalism, J. EcoN. PERSPS., Fall 1997, at 43, 45. This desire to internalize externalities explains why competition policy is carried out by the federal government in the United States and by the regional government in the EU. 
Thus, putting aside political economy issues (discussed below), the real impediment to achieving an optimal policy is transaction costs. Because the interests of net importers and exporters diverge, cooperation can only be achieved through transfers from prospective winners to prospective losers. It follows that ad hoc attempts at cooperation, limited to competition policy alone, stand little chance of success: States that stand to gain from a particular agreement have no way to compensate those that stand to lose. Negotiation over competition policy must occur in a sufficiently broad institutional context to allow for compensation in other areas such as trade or the environment. ${ }^{12}$ The negotiation of transfer payments through concessions in other areas of negotiation is, of course, difficult. This difficulty, however, is unavoidable because without it, cooperation at a substantive level is likely impossible. Before considering the possible forms of cooperation, I now turn to discuss the main arguments advanced in opposition to cooperation.

II.

\section{The Problematic Case Against Cooperation}

The problems of noncooperative policymaking, combined with the realities of international business activity, make it impossible to defend the status quo as an optimal competition policy regime. If there were a well-functioning international governmental system, the case for making antitrust policy decisions at that level would be irrefutable. Because the case against international regulation fails as a matter of theory, sophisticated opponents of international cooperation argue, as they must, that cooperation is too difficult or too costly as a matter of practice. The most common and powerful argument is that policymaking at the international level is too inefficient, undemocratic, and corrupt to be trusted with competition policy. ${ }^{13}$ Even skeptics of international cooperation must admit, though, that it has proven effective in some instances. Few, if any, observers would argue that the General Agreement on Tariffs and Trade, the Trade-Related Aspects of Intellectual Property Rights Agreement, the Basle Accord, the North American Free Trade Agreement, and the EU have all generated net social costs. That said, there is no doubt that international agreements come with costs. The question in any given case is whether the costs outweigh the benefits.

The greatest risk posed by international cooperation in antitrust is that the international process itself will generate undesirable outcomes-foremost, because negotiators might favor the interests of certain groups over those of others.

12. See Andrew T. Guzman, International Antitrust and the WTO: The Lesson from Intellectual Property, 43 VA. J. INT'L L. 933 (2003) (arguing that the TRIPS agreement was possible because negotiations took place in the WTO, where transfer payments are possible).

13. For a generalized argument opposing international cooperation on these grounds, see Paul B. Stephan, Regulatory Competition and Competition: The Search for Virtue, in Transatlantic Regulatory Cooperation: Legal Problems and Poltrical Prospects 167-202 (George A. Bermann et al., eds., 2000); Paul B. Stephan, Accountability and International Lawmaking: Rules, Rents, and Legitimacy, 17 Nw. J. INT'L L. \& Bus. 681 (1996-97); Paul B. Stephan, The Futility of Unification and Harmonization in International Commercial Law, 39 VA. J. INT'L L. 743 (1999); Paul B. Stephan, The Political Economy of Choice of Law, 90 GEO. L.J. 957 (2002). 
For example, business interests may enjoy greater influence than consumer interests, generating a bias toward lenient rules. But while public choice problems will certainly occur at the international level, there is no way to know how large these effects will be or if they will be larger or smaller than the corresponding domestic problems.

As a first cut, international public choice problems are likely to reflect domestic public choice problems. That is, interest groups will be able to influence negotiators because they can influence the politicians who control the negotiators. This influence is not created by internationalization but, rather, by the political structure of domestic government. If policy is made domestically, the same interest group biases will be present. Furthermore, international negotiations may help to reduce the power of interest groups. Interest groups in one country may have significant control over policy, but when governments must negotiate with one another, powerful interest groups in one state may be offset by opposing groups in another. For example, trade agreements counter protectionist pressure by giving policymakers the ability to open foreign markets and thereby please exporters. The net result is less influence on policy for import competing industries and freer trade. Given the clear evidence that a noncooperative regime frustrates domestic policies, it seems appropriate to demand that skeptics advance a more precise model of the political economy of domestic and international policymaking to support their account of international public choice problems.

John McGinnis offers the most comprehensive extant attempt to show that public choice problems on the international level are likely to generate higher costs than domestic regulation. ${ }^{14}$ Although his arguments have some theoretical merit, their validity in any particular context turns on empirical questions that cannot be resolved here. More importantly, the modest level of proposed cooperation in international antitrust fails to trigger most of the costs McGinnis identifies. McGinnis's principal concern is that international negotiators and functionaries have an interest in generating complex rules or other devices to maximize their own influence. But this legitimate concern is not a reason to resist cooperation altogether. The same problem exists and, in the competition policy context, is much more acute domestically. International bureaucrats have considerably less rule-making authority than their domestic law counterparts, so they have a more limited ability to pursue their own interest in this way. Outside the EU and a very small number of "quasi-judicial" bodies, there are very few, if any, instances in which international bureaucrats have any policymaking authority independent of national governments. In the area of international antitrust, no serious proposal exists for an international antitrust agency

14. See John O. McGinnis, The Political Economy of International Antitrust Harmonization, in Competition Laws in Conflict: ANTITRUSt JuRisdiction In THE Global Economy (Michael S. Greve \& Richard A. Epstein eds., 2004) [hereinafter Competition Laws in Conflict]. 
authorized to develop its own rules and policies. ${ }^{15}$ In other words, international cooperation in antitrust can and should proceed without significant bureaucracy.

Ultimately, the issue here concerns the form of cooperation rather than its merits. If cooperation is desirable, concerns about bureaucracy should not frustrate it. To the extent bureaucratic capture is a concern, there should be less delegation to those bureaucrats. ${ }^{16}$

Along similar lines, McGinnis expresses concern about the enforcement of a cooperative regime. He argues that centralized enforcement entails significant costs while decentralized enforcement leads to the problem of divergent standards. Though a regime of harmonization might well present that dilemma, a more modest level of cooperation (described below) avoids it. An adjudicatory body - such as the World Trade Organization's Appellate Body-could adjudicate disputes that arise with respect to a small number of general rules while leaving other issues to the states themselves. That arrangement would also leave room for innovation and experimentation and, in that fashion, allay McGinnis's fears over the rigidity and inflexibility of international institutions.

Two additional arguments against international antitrust cooperation warrant a brief discussion. First, in antitrust, as in many other areas, the internationalization of business activity can and has been viewed as a welcome challenge and discipline for regulators. Until the Alcoa case (1945) in the United States and the Wood Pulp decision (1988) in Europe, for example, activities that took place offshore but had an effect in the jurisdiction were (at least arguably) beyond the reach of local authorities. ${ }^{17}$ Even today, many countries make no attempt to exercise jurisdiction over foreign conduct. Where national law is applied on a strictly territorial basis, it may fail to reach conduct that is alleged to impose harm on local interests. If one believes that existing domestic antitrust laws are excessively tough (or, indeed, entirely unnecessary), internationalization that removes conduct from the local jurisdiction may be seen as desirable. On this view, the internationalization of business corrects a failure of the domestic political system and reduces the authority of local regulators in a desirable way. As McGinnis puts it, "[F]oreign bias may counteract the public

15. A proposed "International Antitrust Code" includes the establishment of an "International Antitrust Authority" that arguably would possess some of the bureaucratic characteristics that concern McGinnis. See International Antitrust Code Working Group, Draft International Antitrust Code as a GATT-MTO-Plurilateral Trade Agreement (July. 10, 1993), 65 Antitrust \& Trade Reg. Rep. (BNA) S-1, Issue No. 1628 (Aug. 19, 1993) (Special Supp.). For a discussion of the Draft Code, see Daniel J. Gifford, The Draft International Antitrust Code Proposed At Munich: Good Intentions Gone Awry, 6 MINN. J. GLobal TRADE 1 (1997). This proposal, however, was advanced in 1993 and does not seem to have generated any significant support. Were it made as a serious proposal today, I would share many of McGinnis's objections.

16. Ultimately, the dispute here turns on empirical questions. I have previously outlined my views on how to proceed with international cooperation in the face of the inevitable uncertainty regarding public choice issues. See Andrew T. Guzman, Public Choice and International Regulatory Competition, 90 Geo. L.J. 971, 977-80 (2002).

17. United States v. Aluminum Co. of America, 148 F.2d 416 (2d Cir. 1945); Case 89/85, In re Wood Pulp Cartel, 1988 E.C.R. 5193. 
choice driven biases against wealth maximizing laws and thus move competition law toward a more optimal state." 18

The readiest-and sufficient-reply is that this argument ignores the current state of international antitrust. Both the United States and the EU, among others, now apply their laws to conduct that takes place abroad but has local effects. Rather than undermining the authority of local regulators, a failure to cooperate will generate overlapping jurisdictional claims and, at least among developed states, more rather than less regulatory review.

Second, and finally, one could argue that a global market reduces the potential for monopolization or other anticompetitive conduct to the point of rendering antitrust law unnecessary. Trade can certainly substitute for competition policy in some instances. The clearest example is a small, closed economy in which local monopolies harm consumers. Opening the country to foreign trade would undermine the market power of local firms and force them to compete. Trade here works as a substitute for competition policy, with the added advantage of promoting competition without government intervention.

Still, trade is not a full substitute for competition policy. Trade can only undermine monopolies that rely on trade barriers for their existence. When firms have international market power, one would expect them to behave as monopolists just like domestic firms with market power. Although it may be more difficult to establish and maintain market power internationally, there is no reason to believe that it is impossible or, for that matter, rare. Industries such as pharmaceuticals, passenger aircraft, and software illustrate the phenomenon.

\section{III.}

\section{THE Form OF COOPERATION}

Although international cooperation on competition policy is necessary, its critics are right that cooperation carries costs. As decisions are moved further from individual citizens, democratic control is weakened. For this and other reasons, special efforts may be necessary to rein in international bureaucracies. Cooperation can be frustrated by weak and unreliable international enforcement mechanisms. And of course, international agreements involve transaction costs. They are slow to negotiate, distract officials from other tasks, and can cause animosity among states. Even when negotiations are successful, the ensuing cooperation can be costly, especially if new institutions are needed. Once completed, these same costs, typically coupled with a unanimity requirement, make international agreements difficult to change. Attempts to reduce the cost of change by delegating authority to international bureaucrats generate their own costs in the form of entrenchment and lack of democratic control.

18. McGinnis, supra note 14 (manuscript at 17 , on file with author). 
To reduce these inevitable costs, the preferred form of cooperation is the lowest level that avoids the distortions of noncooperative policymaking. ${ }^{19} \mathrm{Co}-$ operative strategies on international competition policy come in essentially three forms, from lowest to highest levels of cooperation: voluntary information sharing and consultation (the system that currently exists); procedural cooperation on choice-of-law rules, with an eye toward restricting the number of legal systems claiming jurisdiction; and substantive cooperation, which imposes on states more or less demanding requirements in terms of their domestic substantive rules. A review of these options shows that effective regulation of antitrust requires at least some cooperation with respect to substantive laws. Although such a strategy has drawbacks, including the fact that it may be difficult to reach any agreement, it represents the only way for states to address the externalities associated with international competition policy.

\section{A. Information Sharing}

Faced with continuing growth in international business activity, domestic antitrust authorities have been forced to adopt new strategies. Without at least some sharing of information among national regulators, it would often be difficult to build a case against international firms. If prosecutors were helpless beyond their own borders, a firm could violate the law with little risk by keeping key documents offshore, holding offshore meetings among participants in the violative activity, and residing in a foreign jurisdiction. To prevent erosion of their authority and enforcement powers, antitrust authorities have cooperated with one another.

With few exceptions, cooperation has been limited to voluntary information-sharing agreements. ${ }^{20}$ A typical agreement calls for the sharing of information between enforcement authorities when the actions of regulators in one country affect the interests of the other state. ${ }^{21}$ In addition, the agreements provide for consultation to resolve concerns between the states, indicate that the parties should cooperate in enforcement when possible, and call for each state to take into account the effects of anticompetitive conduct on the other state when considering an enforcement action. This last element (taking the effect of domestic conduct on other states into account) would go a long way toward ad-

19. I have previously written on the question of how to manage cooperation in a wider set of regulatory areas. See Andrew T. Guzman, Choice of Law: New Foundations, 90 GEo. L.J. 883 (2002).

20. See Eleanor M. Fox, Antitrust and Regulatory Federalism: Races Up, Down, and Sideways, 75 N.Y.U. L. REv, 1781, 1785-88 (2000).

21. See, e.g., Agreement Between the Government of the United States of America and the Government of Canada Regarding the Application of Their Competition and Deceptive Marketing Practices Laws, Aug. 3, 1995, U.S.-Can., reprinted in Trade Reg. Rep. (CCH) 4, II 13,503; Agreement Between the Government of the United States of America and the Government of the Federal Republic of Germany Relating to Mutual Cooperation Regarding Restrictive Business Practices, June 23, 1976, U.S.-F.R.G., 27 U.S.T. 1956. The United States has entered into similar agreements with Australia, the European Communities, Israel, Japan, Brazil, and Mexico. For a detailed discussion, see John J. Parisi, Enforcement Cooperation among Antitrust Authorities, 12 INT'L Q. 691 (2000); see also Spencer Weber Waller, The Internationalization of Antitrust Enforcement, 77 B.U. L. REv. 343 (1997). 
dressing the problems with the existing international competition policy regime. Unfortunately, existing agreements do not lay out any details about how this consideration is to be given, do not include any sort of sanction for a failure to take the interests of the other party into account, and say nothing about how the interests of other states should affect domestic policy decisions.

Although these information-sharing agreements play an important role in international antitrust enforcement, they are not and cannot be a solution to the problem of international cooperation. There is, for example, no coordination of substantive laws, no compromise of domestic control, ${ }^{22}$ and no minimum standards. Furthermore, compliance is voluntary. Each state is free to refuse cooperation when it wishes and remains guided by its own interests in deciding when to do so.

Information sharing, or "soft" cooperation, has also been pursued at the Organisation for Economic Co-operation and Development, which has generated several aspirational texts. ${ }^{23}$ None of these impose obligations on states, and they are not intended to do so. Their goals are modestly limited to improving communication on competition issues. This dialogue-and, more recently, multilateral cooperation through the International Competition Network-is important and may have contributed to greater harmonization of substantive laws than would otherwise exist. ${ }^{24}$ Still, it barely exceeds the level one would expect from self-interested states and administrative agencies seeking to preserve their own influence. ${ }^{25}$ By sharing information, enforcement agencies cooperate in such a way as to allow both themselves and their sister agencies to continue their work, but they do not surrender any of their authority over domestic matters. This form of soft cooperation furthers the enforcement goals of regulators but does virtually nothing to address the over- and underregulation of antitrust at the international level.

22. There are two significant exceptions. Canada and the United States have entered into the Treaty on Mutual Legal Assistance in Criminal Matters, Mar. 18, 1985, Can.-U.S., 24 I.L.M. 1092, which provides for the use of compulsory powers to gather evidence in criminal antitrust cases and allows the exchange of compulsory information. The United States has also entered into an agreement with Australia under the International Antitrust Enforcement Assistance Act of 1994, Pub. L. No. $103-438$ (codified at 15 U.S.C. $\$ \$ 6201-12(2000)$ ).

23. See, e.g., The OECD Guidelines for Multinational Enterprises (rev. 2000), available at http://www.oecd.org/dataoecd/56/36/1922428.pdf; Council Recommendation Concerning Action Against Restrictive Business Practices Affecting International Trade Including Those Involving Multinational Enterprises, OECD Doc. C (78)133 (Final) (Aug. 9, 1978), 17 I.L.M. 1527; Recommendation of the Council Concerning Effective Action Against Hard Core Cartels, OECD Doc. C(98)35 (Final) (May 13, 1998), available at http://www.oecd.org/dataoecd/39/4/2350130.pdf.

24. See Diane P. Wood, Soft Harmonization Among Competition Laws: Track Record and Prospects, 48 ANTTTRust Bull. 305, 315 (2003).

25. See Parisi, supra note 21, at 691 ("As business concerns have increasingly pursued foreign trade and investment opportunities, antitrust compliance issues have arisen which transcend national borders and, thus, have led antitrust authorities in the affected jurisdictions to communicate, cooperate, and coordinate their efforts to achieve compatible enforcement results."). 


\section{B. Choice of Law}

Stepping one rung higher on the cooperative ladder, states could set the terms of their interaction through choice-of-law rules that assign jurisdiction (based on some criteria) to one or more states. The criteria for such a selection are familiar and include factors such as the location of the disputed activity and the principal place of business of the firm. But choice-of-law rules cannot, without more, address the problems of over- and underregulation. A choice-of-law system that allows for overlapping jurisdiction leaves the problem of overregulation unresolved. A system that assigns jurisdiction to a single state can reduce the problem of overregulation but may exacerbate the problem of underregulation. Nor can a choice-of-law strategy prevent local favoritism and trade-induced distortions of national substantive policies.

Theoretically, the problem of underregulation in states that cannot extend their laws extraterritorially could be addressed through a choice-of-law rule that grants standing to plaintiffs if the relevant firm activity took place within the jurisdiction, even if the injuries occurred abroad. (An even more aggressive rule would grant standing to any plaintiff regardless of where the conduct took place.) This rule would give injured plaintiffs a remedy against the actions of foreign firms that target states whose laws do not apply extraterritorially, as long as the conduct was within a state with effective antitrust rules. Such a rule would at a minimum ensure that Western firms faced some regulation when selling into countries without extraterritorial reach. The justification for this rule is essentially the same as the justification for eliminating export cartels exemptions: It requires states to pursue some anticompetitive behavior. The Supreme Court's recent ruling in F. Hoffmann-La Roche v. Empagran ${ }^{26}$ establishes that American law does not apply to foreign plaintiffs in this circumstance. In that case, the Court found that the jurisdictional reach of the federal antitrust laws does not extend to conduct with a direct, substantial, and reasonably foreseeable effect on U.S. commerce if the transaction at issue took place wholly outside the United States. If one concludes, as this case suggests, that the adoption and operation of a rule like the one described above is unlikely, the lesson is that deeper cooperation is needed.

\section{Deep Cooperation}

Once it is accepted that cooperation with respect to substantive laws is required, the question becomes how to achieve it. Experience and theory show that a substantive agreement will be difficult to reach because the transaction costs of negotiation in this context are significant. The challenge, then, is to reduce transaction costs as much as possible.

I have argued elsewhere that the WTO represents the best forum for negotiations on the subject. ${ }^{27}$ Regardless of the chosen forum, however, the distortion

26. No 03-724, 2004 U.S. LEXIS 4174 (June 14, 2004).

27. See Andrew T. Guzman, Antitrust and International Regulatory Federalism, 76 N.Y.U. L. Rev. 1142, 1156-58 (2001); Andrew T. Guzman, Global Governance and the WTO, HARv. INT'L 
of domestic incentives cannot be corrected short of cooperation on substantive competition policy. This need not take the form of harmonization because states may conclude that policy differences across regimes are desirable, but it does require negotiation over substantive policy in a forum where transfers are available. For the reasons noted, it seems prudent to start with a relatively modest agenda-without foreclosing greater cooperation in the future.

The most plausible agenda item is a nondiscrimination principle. ${ }^{28}$ This would ideally include both national treatment and most favored nation components, although national treatment is the more important element. Work by McGinnis $^{29}$ and by Trebilcock and Iacobucci, ${ }^{30}$ as well as my own past writing, support the notion of a national treatment requirement. ${ }^{31}$ A national treatment obligation appeals to our sense of fairness, is consistent with the spirit of existing WTO obligations, and would address export cartel exemptions.

Although a national treatment obligation could eliminate explicit discrimination, it would be less successful at addressing the problem of discrimination in application and enforcement. In attempting to deal with discriminatory enforcement, Trebilcock and Iacobucci observe that international trade law addresses the problem of de facto discrimination in other contexts. The antitrust context, however, differs from other areas where discrimination is prohibited. In the trade context, for example, discrimination against an imported product is relatively easy to identify by comparing the treatment of one product with the treatment of another "like product." One can carry out a meaningful inquiry, for example, into the question of whether a country treats imported watches differently from locally produced watches. This sort of comparison is much more difficult in the antitrust context because each prosecution turns on a unique set of facts. It will not typically be the case, for instance, that the prosecution of an alleged international price-fixing scheme can be reviewed by looking at a domestic scheme carried out in the same fashion and in the same industry. A lack

L.J. (forthcoming 2004). At least two of the chapters in Competrion Laws in Conflict, supra note 14, argue against the inclusion of competition policy in WTO negotiations. See Michael Trebilcock \& Edward Iacobbucci, National Treatment and Extraterritoriality: Defining the Domains of Trade and Antitrust Policy, in CompetrTion Laws IN Conflict, supra note 14 (manuscript at 31-33, on file with author); Paul B. Stephan, Competitive Competition Law?: An Essay Against International Cooperation, in COMPETTIION LAwS IN CONFLICT, supra note 14 (manuscript at 21-22, on file with author).

28. One could argue that the WTO's national treatment obligation in art. III:4 of the GATT applies to antitrust rules. I take no position on the applicability of this provision and simply note that the Doha Declaration's charge to the WTO Working Group in Trade and Competition Policy to consider nondiscrimination suggests that there is at least serious doubt about the applicability of the most-favored-nation (MFN) and national treatment clauses. See Ministerial Declaration, Doha Ministerial Conference Fourth Session, WTO Doc. WT/MIN(01)/DEC/1 (Nov. 20, 2001), at $\mathbb{2} 25$, avail . able at http://www.wto.org/english/thewto_e/minist_e/min01_e/mindecl_e.pdf [hereinafter Ministerial Declaration].

29. See McGinnis, supra note 14.

30. See Trebilcock \& Iacobucci, supra note 27.

31. See Guzman, Antitrust and International Regulatory Federalism, supra note 27, at 1162. Trebilcock, Iacobbucci, and McGinnis resist labeling a nondiscrimination provision as substantive harmonization, although it is hard to know what else to call an obligation that forbids states from adopting substantive rules or practices that favor locals over foreigners. 
of a closely analogous set of facts will often obviate comparisons. True, some benchmarks (such as the Hirfindahl-Herschman Index, or HHI) may permit comparisons, but even in those cases, the prosecution of antitrust violations involves much more discretion and case-specific facts than a conventional trade case.

Moreover, other areas subject to nondiscrimination requirements are not always policed effectively, and the national treatment obligation is often more of a de jure than a de facto standard. This is especially true in areas where factspecific inquiries are involved, as would be the case in antitrust. Under the WTO's Agreement on the Application of Sanitary and Phytosanitary Measures, for example, WTO members may adopt measures necessary "for the protection of human, animal or plant life or health." ${ }^{32}$ As applied, this requirement is extraordinarily modest, requiring only that there be a rational relationship between the disputed measure and the required risk assessment. ${ }^{33}$ Similar nondiscrimination requirements exist in other parts of the WTO agreements, and where the obligations go to nontrade issues, the result is virtually always the same: De facto discrimination is largely ignored because the WTO is hesitant to secondguess domestic decisions with respect to such policies.

A national treatment obligation for antitrust, then, is useful primarily to prevent the use of export cartel exemptions and perhaps to constrain egregious forms of de facto discrimination. It cannot prevent regulators from favoring locals in the day-to-day administration of the law or, for that matter, resolve the problems associated with the domestic adoption and enforcement of rules to govern international activity, for example, the strategic choice of domestic law by states engaged in trade.

The slightly more ambitious WTO agenda for reform is a good first step toward more meaningful cooperation. This approach would focus on "core principles, including transparency, non-discrimination and procedural fairness, and provisions on hardcore cartels; [and] modalities for voluntary cooperation. . . ."34 Seeking cooperation on the most agreed upon violations such as hard-core cartels is sensible, as are efforts to increase transparency and voluntary cooperation. Eventually, it would be helpful to see other forms of cooperation emerge, including mandatory information-sharing arrangements (subject to appropriate confidentiality provisions), ${ }^{35}$ streamlining and cooperation in inter-

32. Agreement on Sanitary and Phytosanitary Measures, Apr. 15, 1994, Agreement Establishing the World Trade Organization, Annex 14, in Final Act Embodying The Results Of The Uruguay Round Of Multr.ateral Trade Negotiations, Marrakesh, 14 Apr. 1994, at 69 (1994).

33. Id. art. 5; see, e.g., Michael J. Trebilcock \& Robert Howse, The Regulation of InTERnational TRADE 147, (2d ed. 1999) ("[I]f countries generally feel committed to adopting more stringent health, safety, consumer protection, environmental or conservation standards ... they remain largely free to do so, subject to demonstrating that there is some rational scientific basis for their actions ... . and that such measures do not gratuitously encumber international trade.").

34. Ministerial Declaration, supra note 28, II 25.

35. See McGinnis, supra note 14 (manuscript at 28 , on file with author) (supporting the notion that nations should be required to "permit the extraterritorial application of another nation's laws, at 
national merger review, ${ }^{36}$ and jurisdictional agreements. Cooperation of the sort described here is difficult to achieve, but it is the only way to attain a sensible competition regime in our globalizing world.

least on the same antitrust theories deployed by the nation whose producers are the target of antitrust enforcement").

36. For example, a firm proposing to merge might be required to seek approval for the merger from only one or two states (perhaps its home states or the state with the most affected consumers), and the same forms could then be submitted (with translations if necessary) to authorities in other states who would have the option of requesting further submissions. 